Article

\title{
Development of Sakon Nakhon Rice Variety for Blast Resistance through Marker Assisted Backcross Breeding
}

\author{
Nawaporn Srichant ${ }^{1}$, Sompong Chankaew ${ }^{1}$ (D) Tidarat Monkham ${ }^{1}$, \\ Petcharat Thammabenjapone ${ }^{2}$ and Jirawat Sanitchon ${ }^{1, *}$ \\ 1 Department of Agronomy, Faculty of Agriculture, Khon Kaen University, Khon Kaen 40002, Thailand; \\ giantsummerbook@gmail.com (N.S.); somchan@kku.ac.th (S.C.); tidamo@kku.ac.th (T.M.) \\ 2 Department of Entomology and Plant Pathology, Faculty of Agriculture, Khon Kaen University, \\ Khon Kaen 40002, Thailand; petsir@kku.ac.th \\ * Correspondence: jirawat@kku.ac.th; Tel.: +66-81567-4364
}

Received: 28 December 2018; Accepted: 30 January 2019; Published: 1 February 2019

\begin{abstract}
The Sakon Nakhon (SKN) rice cultivar is non-photosensitive, rich in aroma, and an excellent choice for cooking quality; which adapts well to both upland and lowland conditions. Furthermore, it has been adopted by Thailand's sugarcane growers, as it has proved fit for an upland crop preceding the sugarcane cropping system. However, SKN is very susceptible to blast disease caused by Pyricularia oryzae. The purpose of this study was to breed SKN for blast resistance, using marker-assisted backcrossing, together with phenotypic selection. The breeding population was constructed by crossing the SKN (recurrent) with the RD6 introgression line (donor), which contained four blast resistant quantitative trait loci (QTLs). Franking microsatellite markers for blast resistance QTLs on chromosomes 1, 2, 11 and 12 were used for selection through $\mathrm{BC}_{2} \mathrm{~F}_{2}$. Thirteen $\mathrm{BC}_{2} \mathrm{~F}_{3}$ selected lines were evaluated under greenhouse conditions, and seven lines of $\mathrm{BC}_{2} \mathrm{~F}_{4}$ were evaluated against blast, along with their agronomic traits, under field conditions (upland and lowland). SKN 39-10-19-29-12 and SKN 39-10-19-29-13 presented high resistance to leaf and neck blast; and were non-photosensitive, with the same agronomic traits as the SKN. This study successfully demonstrates the improvement of the recommended SKN variety blast resistance, while maintaining similar agronomic traits.
\end{abstract}

Keywords: bimodal rain; introgression line; microsatellite; QTL; gene pyramiding

\section{Introduction}

Rice (Oryza sativa L.) is the most important economic crop of Thailand. Grown in both lowland and upland conditions, Thailand has remained Southeast Asia's largest rice exporter for several decades. More than $50 \%$ of Thailand's rice production area (about 6.4 Mha in 2014) belongs to its Northeastern region, which is Thailand's largest area of rain-fed rice production [1]. The most popular varieties are RD6 and KDML105, which are lowland aromatic glutinous and non-glutinous rice varieties, respectively [2,3]. More than $0.8 \mathrm{Mha}$ of Northeast Thailand has the capacity to grow upland rice. The climate is drier than other regions, yet proves suitable for growth, as upland rice needs less water to grow [4]. Farmers generally grow upland rice as the major crop for household consumption, or by rotation cropping with sugarcane or cassava to increase their income, and improve soil fertility [5].

Sakon Nakhon rice variety is only one of the recommended upland rice varieties released by Department of Agriculture (DOA) within the past twenty years. This variety is high yielding, and can adapt to both lowland and upland conditions; thus making it the most popular variety of use 
in Northeastern Thailand [6,7]. Derived from a cross of Hom Om and RD10, Sakon Nakhon has numerous beneficial characteristics, such as non-photosensitivity within 128 days to maturity, long and slender grain, and high aroma; which is similar to the RD6. However, it is very susceptible to blast disease. Rice blast is a devastating disease, which is a limiting factor in rice cultivation worldwide, and can cause annual yield losses up to 50\% [8]. The causal pathogen of blast, known as Magnaporthe oryzae Sacc, occurs within sexual reproduction, whereas Pyricularia oryzae is recognized under asexual propagation [9]. The disease is harmful throughout the life cycle of rice [10,11], affecting every stage of growth $[12,13]$.

Controlling blast through cultural practice remains difficult due to numerous environmental factors which contribute to the epidemic. Blast spreads quickly during the rainy season, which is characterized with high humidity and a high rate of nitrogen fertilizer application, which further aids disease development [14]. The distribution of rain in a bimodal pattern makes for favourable outbreak conditions in both the seedling-tillering and heading stages, resulting in leaf or neck blast, or panicle blast, respectively [15]. Chemical management, such as the application of probenazole, has been widely used against rice blast by Japanese farmers. However, despite its affordable cost, it has proven to be ineffective in field conditions [16]. Resistant cultivars have therefore become the more desired approach to eliminating rice blast, for both farmers and consumers; as it can decrease fungicide application, is environmentally friendly, and may reduce production costs [17].

Currently, more than 100 rice blast resistance genes and over 350 quantitative trait loci (QTLs) conferring partial to complete resistance have been identified [18]. Among these, $26 \mathrm{R}$ genes (Pib, Pita, Pi54, Pid2, Pi9, Pi2,Pizt, Pi36, Pi37, Pikm, Pi5, Pit, Pid3, pi21, Pish, Pb1, Pik, Pikp, Pia, Pi25, Pid3A4, Pi35, NLS1, Pikh, Pi54rh and Pi54of) have been cloned [19,20]. Although numerous genetic resistance genes have been identified, the emergence of new virulent races of blast pathogens belonging to the heterothallic reproduction and genetic modification of AVR genes have led the pathogen to evolve and adapt, resulting in a lack of varietal resistance [21].

Rice varieties containing multiple resistant genes via gene pyramiding have guaranteed a broad spectrum of resistance; however, they are very difficult to achieve through conventional breeding methods [22,23], which depend upon environmental factors and phenotype selection. As the topic of numerous current studies, blast resistance genes have developed the most resistance from cultivar, indigenous, and wild species; utilized through marker-assisted selection (MAS) [24]. Selection by this approach is highly efficient, as it is not influenced by environmental factors, in which larger populations may be minimized [25]. MAS has provided successful improvements in blast resistance in Thailand. Several breeding lines derived from MAS, such as P0489 (a recombinant line, derived from Azucena $\times$ IR64), which has been identified as a blast resistant line carrying QTLs on chromosomes 2 and 12 [26], and the Jao Hom Nil variety, containing major resistance QTLs located on chromosomes 1 and 11 [27]. Suwannual et al., 2017; [28] proved successful in pyramiding blast resistance ( $q B l 1, q B l 2, q B l 11$ and $q B 112$ ) into RD 6 with MAS. Manivong et al., 2014; [29] employed MAS to improve submergence tolerance and blast resistance, while maintaining a strong fragrance in glutinous rice. Numerous studies have also reported the success of blast resistant gene introgression through MAS [24,30-32].

The objectives of the present study were therefore to improve the Sakon Nakhon upland rice variety for blast resistance using marker-assisted selection, while maintaining its desirable agronomic traits.

\section{Materials and Methods}

\subsection{Population Development and Masker-Assisted Selection}

The progenies of the $\mathrm{BC}_{2} \mathrm{~F}_{4}$ population were developed from a cross between the Sakon Nakhon variety and RD6 NIL. While Sakon Nakhon is a blast-susceptible variety, the RD6 NIL, derived from genes pyramiding within the cross of RD $6 \times$ Jao Hom Nin and RD $6 \times$ P0489, is a blast-resistant line. The RD6 NIL carries four blast resistant QTLs; located on chromosomes 1 ( $q B l 1), 2$ ( $q B l 2), 11$ 
(qBl11), and 12 (qBl12) [28]. Sakon Nakhon was used as the recurrent parent. F1 populations were backcrossed to the Sakon Nakhon, in order to deliver a $\mathrm{BC}_{1} \mathrm{~F}_{1}$ population, and marker-assisted selection (MAS) was utilized to select resistance alleles. Seven SSR markers franking to four blast-resistant QTLs were employed for MAS, including RM319/RM212 (qBl1), RM48/RM207 ( $q B l 2)$, RM144/RM224 ( $q$ Bl11), and RM27933 ( qBl12) (Supplementary Table S1). Total genomic DNA from young leaves from each individual plant, lines, and their parents were extracted according to the method described by Dellaporta et al. [33] with slightly modification. The PCR reactions for SSR markers were carried out in a volume of $10 \mu \mathrm{L}$. The PCR component containing $25 \mathrm{ng}$ of genomic DNA, $1 \times$ PCR buffer, 1.8 $\mathrm{mM} \mathrm{MgCl} 2,0.2 \mathrm{mM} \mathrm{dNTP}, 0.2 \mu \mathrm{M}$ forward and reverse primer, 0.05 unit Taq DNA polymerase. DNA amplification was performed in a DNA Thermal Cycle for $5 \mathrm{~min}$ at $95^{\circ} \mathrm{C}$, followed by 35 cycles of $30 \mathrm{~s}$ at $95{ }^{\circ} \mathrm{C}, 30 \mathrm{~s}$ at $55^{\circ} \mathrm{C}$ and $2 \mathrm{~min}$ at $72{ }^{\circ} \mathrm{C}$, with a final extension of $7 \mathrm{~min}$ at $72{ }^{\circ} \mathrm{C}$. The amplification products were separated on $4.5 \%$ polyacrylamide gel electrophoresis. $\mathrm{BC}_{2} \mathrm{~F}_{1}$ was selected via MAS, and the selected plants were selfed to produce $\mathrm{BC}_{2} \mathrm{~F}_{2}$. Among segregating $\mathrm{BC}_{2} \mathrm{~F}_{2}$ populations, $\mathrm{a}$ homozygous resistance genotype was identified by MAS, and allowed to self to deliver $\mathrm{BC}_{2} \mathrm{~F}_{3}$ for greenhouse validation. The selected lines, similar to Sakon Nakhon, were selected and allowed to self to develop a $\mathrm{BC}_{2} \mathrm{~F}_{4}$ population for field validation (Figure 1).

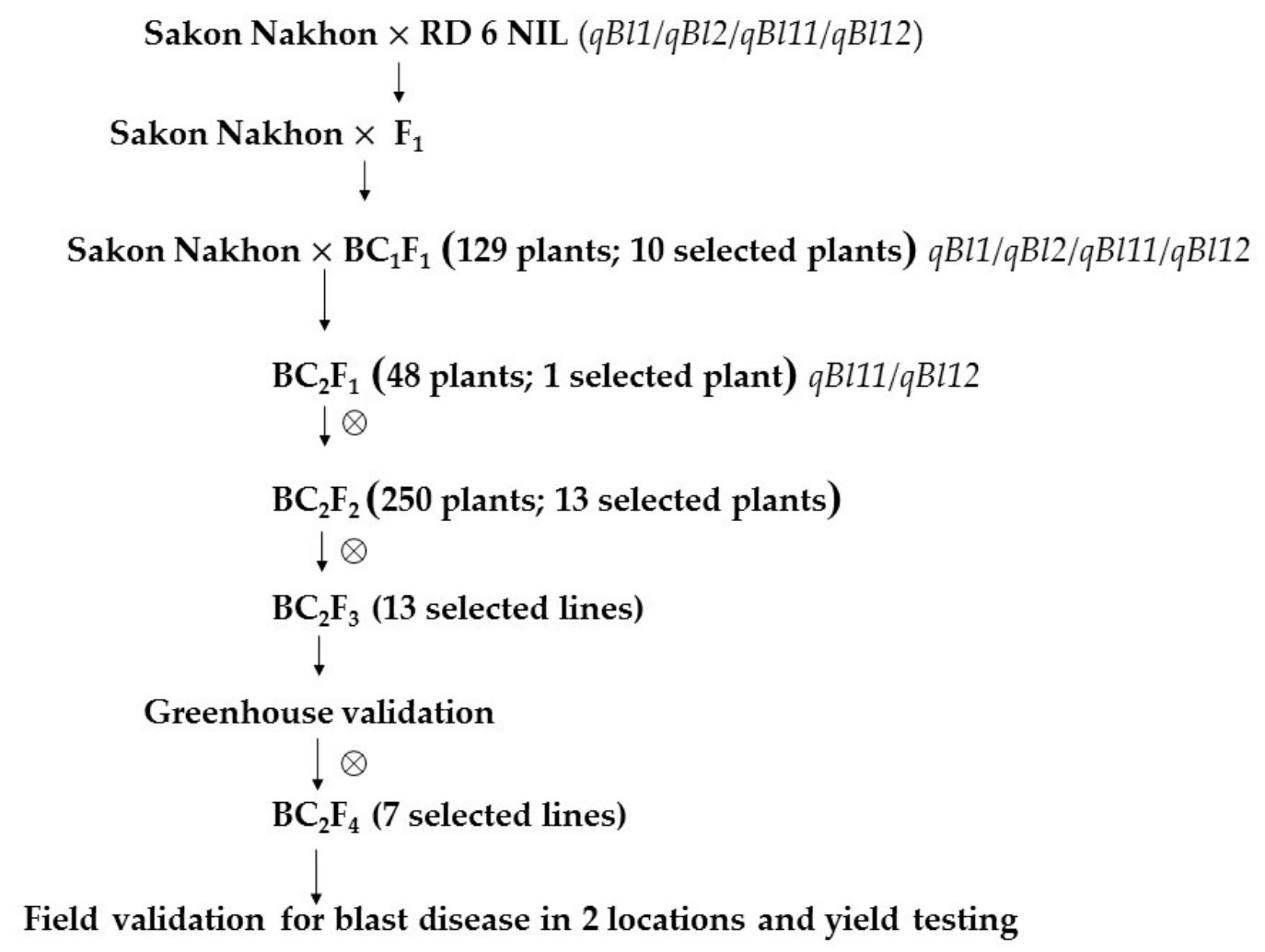

Figure 1. Schematic of present gene introgression into Sakon Nakhon using marker-assisted backcrossing method.

\subsection{Greenhouse Validation}

The parents and thirteen lines of $\mathrm{BC}_{2} \mathrm{~F}_{3}$ progenies of Sakon Nakhon $\times \mathrm{RD} 6 \mathrm{NIL}$, together with four resistant (JHN, IR64, Azucena and P0489) and two susceptible (RD6 and KDML105) check varieties, were evaluated for blast resistant under greenhouse conditions. The experiment was laid out by Complete Randomized Design (CRD) with three replications; rice was planted by direct seeding in plastic trays with five plants/row for each replication. Fertilizer at the rate of $75 \mathrm{~kg} \mathrm{~N} / \mathrm{ha}$ was applied three times; at 9, 11, and 14 days after planting. Evaluation of blast resistance was done at the seedling stage using artificial inoculation at the Ubon Ratchathani Rice Research Center (URRC), Ubon 
Ratchathani, Thailand (2017). An inoculum of P. oryzae was prepared from four different sources of blast isolates in Northeast Thailand (NKI11397, KKN191082, SKN205327, and KKU2016) (Figure 2). Each isolate contained different resistant breaking genes. A purified P. oryzae was multiplied through culturing on rice polish agar, and incubated for ten days under dark conditions at $25+2{ }^{\circ} \mathrm{C}$. Sporulation was induced using sterilized rice leaves, placed on a petri dish, in which mycelium was grown, and then incubated at $25 \pm 2{ }^{\circ} \mathrm{C}$ under fluorescent light for four days. Spore suspensions were counted using a heamacytometer; after which, the concentrations were adjusted to $5 \times 104$ spore $/ \mathrm{mL}$ with sterile distilled water. Inoculation was done by spraying the 21-day-old seedlings, and incubating them in a moist chamber for $48 \mathrm{~h}$; then transferring them to observe blast symptoms within 5-7 days. Blast scoring was carried out in three plants per line, from each replication, following the procedure stipulated in the Standard Evaluation System [34].

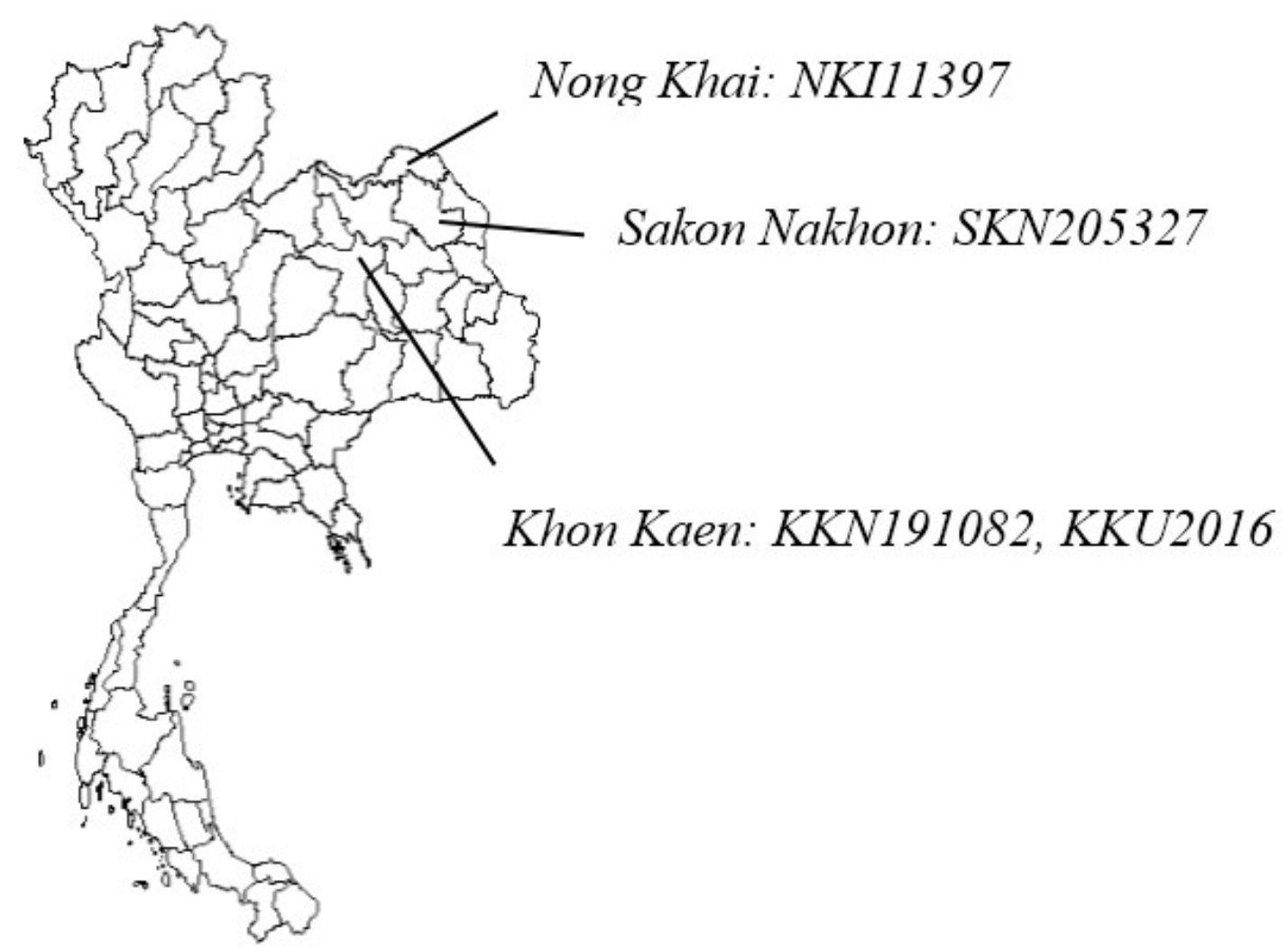

Figure 2. Source of Pyricularia oryzae isolates used for artificial inoculation in greenhouse conditions at Ubon Ratchathani Rice Research Center.

\subsection{Field Validation}

The parents and seven lines of $\mathrm{BC}_{2} \mathrm{~F}_{4}$ progenies of Sakon Nakhon $\times$ RD6 NIL, together with four resistant (JHN, Thanyasirin, P0489 and ULR081) and three susceptible (RD6, KDML105 and ULR082) check varieties were evaluated for blast resistance under field conditions. The experiments were conducted in both lowland and upland locations; (1) the Khon Kaen agriculture field, Khon Kaen University, Thailand; and (2) Ban Haed District, Khon Kaen, Thailand; respectively. The experiments were laid out by a Random Complete Block Design (RCBD) with three replications. Each plot contained four rows, $2 \mathrm{~m}$ in length, spaced $30 \mathrm{~cm}$ and $25 \mathrm{~cm}$ between and within rows, respectively. Each plot was inserted with a trap plant (RD6 and SKN) to induce natural infection. Fertilizer $(23 \mathrm{~kg} / \mathrm{ha}, \mathrm{N}$, $\mathrm{P}_{2} \mathrm{O}_{5}, \mathrm{~K}_{2} \mathrm{O}$ ) was applied at 30 and 60 days after planting. Leaf and neck blast scores were recorded from 16 plants within the inner rows of each plot, followed by IRRI [33]. The traits relating to the agronomic characteristics were also observed, within the Ban Haed District only. Agronomic traits and yield components; including days to flowering $(\mathrm{DF})$, plant height $(\mathrm{PH})$, number of effective tiller per 
plant (NETP), number of grains per panicle (NGP), panicle length (PL), 1000 grain weight (TGW), and grain yield (GY) were measured from four plants within the inner rows of each plot.

\subsection{Evaluation of Seed Quality}

Seed quality was measured using seed samples harvested from the field in the Ban Haed District of Khon Kaen, and fragrance evaluation was determined by sensory test [35]. Morphological aspects of the rice seeds, including brown rice and whole grain size, were examined through seed length and breadth measurements, and length/breadth ratio (L/B ratio).

\subsection{Data Analysis}

Blast scores, agronomic traits, and seed quality of lines and varieties were analyzed via STATISTIC 10 program (Copyright $^{\circledR}$ 1985-2013, Analytical Software 2105 Miller Landing Rd. Tallahassee, FL, USA) means were compared by least significant difference (LSD), blast severity index (SI) was estimated following Sirithanya, 1998 [36]; and broad-spectrum resistance (BSR) was also estimated [37].

\section{Results}

\subsection{Development of Backcross Introgression Lines (ILs) via MAS}

Thirty-nine F1-plants were obtained through crossing SKN and RD6 NIL; all of which were heterozygous after confirmation by RM 319, which proved polymorphic between the two parental lines. $\mathrm{F} 1$ was crossed back to the SKN recurrent parent, in which $129 \mathrm{BC}_{1} \mathrm{~F}_{1}$ plants were derived, and ten individual plants were identified as heterozygous resistant at four QTLs. Forty-eight of the $\mathrm{BC}_{2} \mathrm{~F}_{1}$ plants were developed similarly to the $\mathrm{BC}_{1} \mathrm{~F}_{1}$. However, due to the small population size, the backcross progenies did not cover all re-combinations of the four QTLs. Results showed that only one of the $\mathrm{BC}_{2} \mathrm{~F}_{1}$ SKN 39-10-19 carried the blast QTL on chromosomes 11 and 12. This line was consequently selected for self-pollination. Two hundred and fifty $\mathrm{BC}_{2} \mathrm{~F}_{2}$ plants were derived, in which 13 lines were identified as homozygous resistant for QTLs on chromosomes11, 12, and11/12; further producing $\mathrm{BC}_{2} \mathrm{~F}_{3}$ through $\mathrm{BC}_{2} \mathrm{~F}_{4}$ (Figure 1).

\subsection{Blast Resistance Validation}

\subsubsection{Greenhouse Validation}

Thirteen $\mathrm{BC}_{2} \mathrm{~F}_{3}$ introgression lines, their parents, and six check varieties were evaluated for resistance to four isolates of P. oryzae at the Ubon Ratchathani Rice Research Center. Analysis of variance (ANOVA) showed a significance of genotypic mean square $(G)$, whereas isolates (I) and $G \times I$ interaction were not significant (Supplementary Table S2), indicating that the genotype directly affects disease occurrence. The susceptible check varieties (KDML105 and RD6) were highly susceptible with a blast score ranking from 7.16 to 9, and a BSR of 0; whereas the IR 64 the resistance check variety had a BSR of 1. Interestingly; the Jao Hom Nin, Azucena, and P0489 were susceptible to most of the blast isolates with BSRs of 0, 0 and 0.25; respectively (Table 1). The RD6 NIL resisted all blast isolates, whereas the SKN was very susceptible. The SKN introgression lines demonstrated differences in blast resistance due to their different combinations of resistant QTLs (Table 1) on chromosome 11 (SKN 39-10-19-45 and SKN 39-10-19-57) and chromosome 11/12 (SKN 39-10-19-245, SKN 39-10-19-247, SKN 39-10-19-212, SKN 39-10-19-137, SKN 39-10-19-29). The QTL on chromosomes 11 and 11/12 demonstrated successful blast resistance with a BSR of 1 , whereas the lines containing blast resistant QTLs on chromosomes 12 and the SKN line without QTL were susceptible, with a BSR of 0 (Table 1). Our results indicated that a single blast resistant QTL on chromosome 11 contained the same broad spectrum of resistance as the IR64, the international resistance standard check. 
Table 1. Means of the scores for blast disease P. oryzae and reaction to four isolates of the $\mathrm{BC}_{2} \mathrm{~F}_{2: 3}$ population evaluated under greenhouse conditions at the Ubon Ratchathani Rice Research Center in 2017.

\begin{tabular}{|c|c|c|c|c|c|c|c|c|c|c|}
\hline \multirow{3}{*}{$\begin{array}{l}\text { Lines and Varieties } \\
\text { SKN 39-10-19-51 }\end{array}$} & \multirow{3}{*}{$\begin{array}{c}\text { QTLs } \\
-\end{array}$} & \multicolumn{8}{|c|}{ Blast Isolate } & \multirow{3}{*}{$\begin{array}{c}\text { BSR } \\
0\end{array}$} \\
\hline & & \multicolumn{2}{|c|}{ NKI11397 } & \multicolumn{2}{|c|}{ KKN191082 } & \multicolumn{2}{|c|}{ SKN205327 } & \multicolumn{2}{|c|}{ KKU2016 } & \\
\hline & & $9.00 \mathrm{a}$ & VS & $9.00 \mathrm{a}$ & VS & $9.00 \mathrm{a}$ & VS & $8.50 \mathrm{ab}$ & VS & \\
\hline SKN 39-10-19-130 & - & $8.11 \mathrm{ab}$ & VS & $9.00 \mathrm{a}$ & VS & $5.83 \mathrm{bcd}$ & $\mathrm{S}$ & $8.16 \mathrm{ab}$ & VS & 0 \\
\hline SKN 39-10-19-45 & 11 & $0.33 \mathrm{e}$ & $\mathrm{R}$ & $0.83 \mathrm{c}$ & $\mathrm{R}$ & $1.16 \mathrm{e}$ & $\mathrm{R}$ & $0.66 \mathrm{e}$ & $\mathrm{R}$ & 1 \\
\hline SKN 39-10-19-57 & 11 & $0.33 \mathrm{e}$ & $\mathrm{R}$ & $1.00 \mathrm{c}$ & $\mathrm{R}$ & $0.41 \mathrm{e}$ & $\mathrm{R}$ & $1.50 \mathrm{e}$ & $\mathrm{R}$ & 1 \\
\hline SKN 39-10-19-187 & 12 & $7.50 \mathrm{~b}$ & VS & $9.00 \mathrm{a}$ & VS & $4.91 \mathrm{~cd}$ & MS & $6.83 \mathrm{abc}$ & S & 0 \\
\hline SKN 39-10-19-245 & 11,12 & $0.50 \mathrm{e}$ & $\mathrm{R}$ & $1.77 \mathrm{c}$ & $\mathrm{R}$ & $0.83 \mathrm{e}$ & $\mathrm{R}$ & $1.16 \mathrm{e}$ & $\mathrm{R}$ & 1 \\
\hline SKN 39-10-19-247 & 11,12 & $0.58 \mathrm{e}$ & $\mathrm{R}$ & $1.16 \mathrm{c}$ & $\mathrm{R}$ & $0.83 \mathrm{e}$ & $\mathrm{R}$ & $1.00 \mathrm{e}$ & $\mathrm{R}$ & 1 \\
\hline SKN 39-10-19-212 & 11,12 & $0.16 \mathrm{e}$ & $\mathrm{R}$ & $0.72 \mathrm{c}$ & $\mathrm{R}$ & $0.58 \mathrm{e}$ & $\mathrm{R}$ & $1.00 \mathrm{e}$ & $\mathrm{R}$ & 1 \\
\hline SKN 39-10-19-137 & 11,12 & $0.08 \mathrm{e}$ & $\mathrm{R}$ & $0.83 c$ & $\mathrm{R}$ & $0.33 \mathrm{e}$ & $\mathrm{R}$ & $1.41 \mathrm{e}$ & $\mathrm{R}$ & 1 \\
\hline SKN 39-10-19-29 & 11,12 & $0.41 \mathrm{e}$ & $\mathrm{R}$ & $0.66 \mathrm{c}$ & $\mathrm{R}$ & $0.50 \mathrm{e}$ & $\mathrm{R}$ & $0.83 \mathrm{e}$ & $\mathrm{R}$ & 1 \\
\hline P0489 (resistance check) & - & $2.83 \mathrm{~d}$ & MR & $6.00 \mathrm{~b}$ & $\mathrm{~S}$ & $4.83 \mathrm{~cd}$ & MS & $1.16 \mathrm{e}$ & $\mathrm{R}$ & 0.25 \\
\hline KDML105 (susceptibility check) & & $8.50 \mathrm{ab}$ & VS & $9.00 \mathrm{a}$ & VS & $9.00 \mathrm{a}$ & VS & $7.16 \mathrm{abc}$ & S & 0 \\
\hline RD6 (susceptibility check) & & $8.83 \mathrm{a}$ & VS & $9.00 \mathrm{a}$ & VS & $7.50 \mathrm{abc}$ & VS & $8.83 \mathrm{a}$ & VS & 0 \\
\hline F-TEST & & ** & & ** & & ** & & ** & & \\
\hline C.V. $\%$ & & 29.69 & & 25.05 & & 50.97 & & 40.05 & & \\
\hline
\end{tabular}

Reaction to blast disease: VR = Very Resistance, $\mathrm{R}=$ Resistance, MR = Moderate Resistance, MS = Moderate Susceptibility, $\mathrm{S}=$ Susceptible and VS = Very Susceptible; BSR = Broad-spectrum resistance; ${ }^{* *}$ significant at $p=0.05$ by LSD; The letter after value were showed significant within the column. C.V. = Coefficient of variation, QTLS = Quantitative trait loci on chromosome.

\subsubsection{Field Validation}

Seven $\mathrm{BC}_{2} \mathrm{~F}_{4}$ progenies were selected based upon the days to maturity and the SKN plant type. The SKN introgression lines, their parents, and six check varieties were evaluated for their reaction to blast disease under natural infection in the paddy field. Leaf blast symptoms in the lowland field were found to be more severe than in the upland field. The symptoms of the susceptible check varieties (RD6 and ULR082) produced blast scores ranging from 6.56 to 8.78 in the lowland field, and 5.93 to 4.33 in the upland field. Most of the resistance check varieties were lower in blast resistance score (Table 2). Disease occurrence under natural infection in both locations was distinguishable between the two parental lines, in which the RD6 NILs and Thanyasirin were moderately susceptible. The SKN introgression lines carrying the QTL on chromosomes 11 and 11/12 showed significant leaf blast and neck blast resistance; particularly, the SKN 39-10-19-29-12 and SKN 39-10-19-29-13, which carried the blast resistant QTLs on chromosomes 11 and 12. In contrast, the introgression line with a single QTL on chromosome 12 was susceptible (Table 2); indicating that the resistance of chromosome 11 was greater than that of chromosome 12. Interestingly, the RD6 (susceptible check) was neck blast resistant within later flowering (106 days). All introgression lines were resistant to neck blast within the early flowering period (84-90 days), whereas the SKN was susceptible. The result indicated that the SKN introgression lines were both leaf blast and neck blast resistant. 
Table 2. Reaction of the $\mathrm{BC}_{2} \mathrm{~F}_{4}$ population to P. oryzae (leaf blast and neck blast) in two locations under field conditions in the wet season of 2017.

\begin{tabular}{|c|c|c|c|c|c|c|c|}
\hline \multirow{2}{*}{ Lines \& Varieties } & \multirow{2}{*}{ QTLs } & \multicolumn{2}{|c|}{ Leaf Blast } & \multicolumn{2}{|c|}{ Neck Blast } & \multicolumn{2}{|c|}{ Day to Flowering } \\
\hline & & Ban Haed & KKU & Ban Haed & KKU & Ban Haed & KKU \\
\hline SKN 39-10-19-130-6 & - & $1.67 \mathrm{~d}$ & $5.00 \mathrm{c}$ & $9 \mathrm{a}$ & $9 \mathrm{a}$ & 89 hi & $87 \mathrm{~d}$ \\
\hline SKN 39-10-19-57-6 & 11 & $0.00 \mathrm{f}$ & $0.00 \mathrm{~d}$ & $1 \mathrm{c}$ & $1 \mathrm{~d}$ & $92 \mathrm{~g}$ & $88 \mathrm{c}$ \\
\hline SKN 39-10-19-187-9 & 12 & $1.67 \mathrm{~d}$ & $5.84 \mathrm{bc}$ & $7 \mathrm{~b}$ & $8 \mathrm{~b}$ & $92 \mathrm{~g}$ & $84 \mathrm{e}$ \\
\hline SKN 39-10-19-247-7 & 11,12 & $0.33 \mathrm{ef}$ & $0.00 \mathrm{~d}$ & $1 \mathrm{c}$ & $1 \mathrm{~d}$ & $98 \mathrm{~d}$ & $86 \mathrm{~d}$ \\
\hline SKN 39-10-19-137-1 & 11,12 & $0.00 \mathrm{f}$ & $0.33 \mathrm{~d}$ & $1 \mathrm{c}$ & $1 \mathrm{~d}$ & 96 de & $88 \mathrm{c}$ \\
\hline SKN 39-10-19-29-12 & 11,12 & $0.00 \mathrm{f}$ & $0.00 \mathrm{~d}$ & $1 \mathrm{c}$ & $1 \mathrm{~d}$ & 95 ef & $90 \mathrm{~b}$ \\
\hline SKN 39-10-19-29-13 & 11,12 & $0.00 \mathrm{f}$ & $0.00 \mathrm{~d}$ & $1 \mathrm{c}$ & $1 \mathrm{~d}$ & 96 de & $90 \mathrm{~b}$ \\
\hline SKN recurrent parent & - & $1.00 \mathrm{de}$ & $4.78 \mathrm{c}$ & $7 \mathrm{ab}$ & $7 c$ & $93 \mathrm{fg}$ & $89 \mathrm{~b}$ \\
\hline RD6 NIL donor parent & $1,2,11,12$ & $0.00 \mathrm{f}$ & $4.78 \mathrm{c}$ & $1 \mathrm{c}$ & $1 \mathrm{~d}$ & $122 \mathrm{ab}$ & $106 \mathrm{a}$ \\
\hline JHN resistance check & & $0.00 \mathrm{f}$ & $0.00 \mathrm{~d}$ & $1 \mathrm{c}$ & $1 \mathrm{~d}$ & $105 \mathrm{c}$ & $106 \mathrm{a}$ \\
\hline P0489 resistance check & & $0.00 \mathrm{f}$ & $0.00 \mathrm{~d}$ & $1 \mathrm{c}$ & $1 \mathrm{~d}$ & $87 \mathrm{i}$ & $106 \mathrm{a}$ \\
\hline Thanyasirin resistance check & & $3.00 \mathrm{c}$ & $5.00 \mathrm{c}$ & $1 \mathrm{c}$ & $1 \mathrm{~d}$ & $124 \mathrm{a}$ & $106 \mathrm{a}$ \\
\hline ULR081 resistance check & & $0.00 \mathrm{f}$ & $0.00 \mathrm{~d}$ & $1 \mathrm{c}$ & $1 \mathrm{~d}$ & $91 \mathrm{gh}$ & $80 \mathrm{f}$ \\
\hline ULR082 susceptibility check & & $4.33 \mathrm{~b}$ & $8.78 \mathrm{a}$ & $1 \mathrm{c}$ & ND & $120 \mathrm{~b}$ & ND \\
\hline RD6 susceptibility check & & $5.93 \mathrm{a}$ & $6.56 \mathrm{~b}$ & $1 \mathrm{c}$ & $1 \mathrm{~d}$ & $121 \mathrm{ab}$ & $106 \mathrm{a}$ \\
\hline KDML 105 susceptibility check & & - & $9.00 \mathrm{a}$ & - & ND & - & ND \\
\hline Grand Mean & & 1.30 & 3.25 & 2.31 & 2.49 & 101.5 & 93.7 \\
\hline F-test & & ** & ** & ** & ** & ** & ** \\
\hline C.V.\% & & 38.95 & 19.74 & 42.3 & 15.12 & 1.26 & 0.62 \\
\hline
\end{tabular}

** Significant at $p=0.05$ by LSD, KKU $=$ Khon Kean University, ND = No data; the letter after value were showed significant within the column.

\subsection{Agronomic and Yield Performance}

Agronomic traits of the $\mathrm{BC}_{2} \mathrm{~F}_{4}$ population were evaluated at the Ban Haed District field site. The two parental lines (Sakon Nakhon and RD6 NIL) were significant for DF, NGP, TGW and HI traits; yet non-significant for PH, NETP, PL and GY. The means of the agronomic traits of the introgression lines for DF, PH, NEPT, PL, NGP, TGW, HI and GY traits were not significant from SKN; however, seven introgression lines showed similarity to the SKN, the recurrent parent (Table 3).

Table 3. Yield and yield components of the seven lines tested in field conditions at Ban Haed in the wet season of 2017.

\begin{tabular}{|c|c|c|c|c|c|c|c|c|}
\hline Line/Variety & QTLs & PH & NETP & PL & NGP & TGW & HI & GY \\
\hline SKN 39-10-19-130-6 & - & $130 a b$ & 15 efg & $26 \mathrm{ab}$ & $104 \mathrm{~d}$ & $31.2 \mathrm{a}$ & $0.21 \mathrm{a}$ & $3233 \mathrm{abc}$ \\
\hline SKN 39-10-19-57-6 & 11 & $135 \mathrm{a}$ & 18 bcd & $26 \mathrm{ab}$ & $109 \mathrm{~cd}$ & $29.8 \mathrm{ab}$ & $0.17 \mathrm{ab}$ & $2677 \mathrm{abc}$ \\
\hline SKN 39-10-19-187-9 & 12 & $137 \mathrm{a}$ & 17 cdef & $26 \mathrm{ab}$ & $118 \mathrm{bcd}$ & $29.9 \mathrm{ab}$ & $0.19 \mathrm{a}$ & $3236 \mathrm{abc}$ \\
\hline SKN 39-10-19-247-7 & 11,12 & $130 a b$ & $19 \mathrm{bc}$ & $25 \mathrm{abc}$ & $121 \mathrm{bcd}$ & $31.1 \mathrm{a}$ & $0.20 \mathrm{a}$ & 3724 a \\
\hline SKN 39-10-19-137-1 & 11,12 & $140 \mathrm{a}$ & 16 def & $25 \mathrm{bc}$ & $116 \mathrm{~cd}$ & $31.6 \mathrm{a}$ & $0.17 \mathrm{ab}$ & $2618 \mathrm{abc}$ \\
\hline SKN 39-10-19-29-12 & 11,12 & $132 \mathrm{ab}$ & 17 cde & $27 \mathrm{ab}$ & $121 \mathrm{bcd}$ & $29.2 \mathrm{ab}$ & $0.21 \mathrm{a}$ & $3493 \mathrm{ab}$ \\
\hline SKN 39-10-19-29-13 & 11,12 & $127 \mathrm{abc}$ & 17 cdef & $26 \mathrm{ab}$ & 119 bcd & $28.8 \mathrm{ab}$ & $0.21 \mathrm{a}$ & $3123 a b c$ \\
\hline SKN & - & 132. ab & $16 \mathrm{cdef}$ & $27 \mathrm{a}$ & $115 \mathrm{~cd}$ & $30.8 \mathrm{a}$ & $0.19 \mathrm{a}$ & $3489 \mathrm{ab}$ \\
\hline RD6 NIL & $1,2,11,12$ & $120 \mathrm{bc}$ & $19 \mathrm{bc}$ & $27 \mathrm{ab}$ & $154 \mathrm{ab}$ & $27.2 \mathrm{bc}$ & $0.13 \mathrm{bc}$ & $3022 \mathrm{abc}$ \\
\hline JHN & & $84 \mathrm{e}$ & $23 \mathrm{a}$ & $25 \mathrm{bc}$ & $126 \mathrm{bcd}$ & $22.5 \mathrm{~d}$ & $0.13 \mathrm{bc}$ & $2163 a b c$ \\
\hline Thanyasirin & & $116 \mathrm{~cd}$ & $21 \mathrm{ab}$ & $25 \mathrm{abc}$ & $127 \mathrm{bcd}$ & $26.9 \mathrm{bc}$ & $0.12 \mathrm{bcd}$ & $2145 \mathrm{abc}$ \\
\hline P0489 & & $105 \mathrm{~d}$ & $12 \mathrm{~g}$ & $25 \mathrm{abc}$ & $172 \mathrm{a}$ & $22.6 \mathrm{~d}$ & $0.17 \mathrm{ab}$ & $2307 \mathrm{abc}$ \\
\hline ULR081 & & $121 b c$ & $19 \mathrm{bc}$ & $23 c$ & $125 \mathrm{bcd}$ & $29.9 \mathrm{ab}$ & $0.20 \mathrm{a}$ & $3298 \mathrm{abc}$ \\
\hline ULR082 & & $133 a b$ & $14 \mathrm{fg}$ & $26 \mathrm{ab}$ & $132 \mathrm{bcd}$ & $28.6 \mathrm{ab}$ & $0.08 \mathrm{~d}$ & $1568 \mathrm{c}$ \\
\hline RD 6 & & $106 \mathrm{~d}$ & 17 cdef & $27 \mathrm{ab}$ & $143 a b c$ & $24.4 \mathrm{~cd}$ & $0.08 \mathrm{~cd}$ & $1734 \mathrm{bc}$ \\
\hline Mean & & 123 & 17.2 & 25.7 & 127 & 28.3 & 0.17 & 2789 \\
\hline F-test & & $* *$ & ** & $* *$ & $* *$ & $* *$ & $* *$ & ** \\
\hline C.V.\% & & 6.64 & 10.44 & 4.51 & 9.86 & 6.59 & 18.24 & 21.54 \\
\hline
\end{tabular}

** Significant at $1 \%$ probability level; PH = Plant height $(\mathrm{cm}) ;$ NETP $=$ Numbers of effective tillers /hill; PL = Panicle length $(\mathrm{cm}) ; \mathrm{NGP}=$ Numbers of total grains $/$ panicle; TGW = 100 grain weight $(\mathrm{g}) ; \mathrm{HI}=$ Harvest index; GY = Grain yield $\mathrm{kg} / \mathrm{ha}$; the letter after value were showed significant within the column.

The DF, PH, NEPT, PL, NGP, TGW, HI and GY of the SKN were 93 days to flowering, $132 \mathrm{~cm}, 16$, $27 \mathrm{~cm}, 115$ seeds, $30.8 \mathrm{~g}, 0.19$ and 3,489 kg/ha; respectively. Furthermore, two promising introgression lines (SKN 39-10-19-247-7 and SKN 39-10-19-29-12) produced higher grain yields than the SKN at 3724 
and $3493 \mathrm{~kg} / \mathrm{ha}$, respectively (Table 3). Regarding the grain traits, the L/B ratios of SKN whole grain and brown rice were 4.28 and 3.73, respectively, and the $\mathrm{L} / \mathrm{B}$ ratio of the selected lines ranged from 4.07 to $4.44 \mathrm{~mm}$. Most lines showed similarities to the SKN, except for the SKN 39-10-19-137-1. The $\mathrm{L} / \mathrm{B}$ ratio of brown rice ranged from 3.63 to $3.82 \mathrm{~mm}$. which was not significant from the SKN (Table 4), and each of the four SKN introgression lines were rich in aromatic character (Table 4).

Table 4. Comparison of grain quality performance of IL and two parents in the $\mathrm{BC}_{2} \mathrm{~F}_{4}$ population.

\begin{tabular}{|c|c|c|c|c|c|c|c|c|}
\hline \multirow[b]{2}{*}{ Line/Variety } & \multirow[b]{2}{*}{ QTLs } & \multirow[b]{2}{*}{ Fragrance } & \multicolumn{3}{|c|}{ Whole Grain Size } & \multicolumn{3}{|c|}{ Brown Rice Size } \\
\hline & & & Length & Breadth & $\begin{array}{c}\text { L/B } \\
\text { Ratio }\end{array}$ & Length & Breadth & $\begin{array}{c}\text { L/B } \\
\text { Ratio }\end{array}$ \\
\hline SKN 39-10-19-130-6 & - & 1 & $10.81 \mathrm{~b}$ & 2.58 & $4.20 \mathrm{ab}$ & $7.64 \mathrm{c}$ & $2.10 \mathrm{c}$ & $3.64 \mathrm{a}$ \\
\hline SKN 39-10-19-57-6 & 11 & 2 & $11.10 \mathrm{ab}$ & 2.57 & $4.32 \mathrm{ab}$ & $8.14 \mathrm{ab}$ & $2.13 \mathrm{bc}$ & $3.82 \mathrm{a}$ \\
\hline SKN 39-10-19-187-9 & 12 & 1 & $11.63 \mathrm{a}$ & 2.68 & $4.34 \mathrm{ab}$ & $7.98 \mathrm{abc}$ & $2.18 \mathrm{ab}$ & $3.65 \mathrm{a}$ \\
\hline SKN 39-10-19-247-7 & 11,12 & 2 & $11.30 \mathrm{ab}$ & 2.55 & $4.44 \mathrm{ab}$ & $7.94 \mathrm{abc}$ & $2.19 \mathrm{ab}$ & $3.63 \mathrm{a}$ \\
\hline SKN 39-10-19-137-1 & 11,12 & 1 & $11.02 \mathrm{ab}$ & 2.71 & $4.07 \mathrm{~b}$ & 7.87 bc & $2.17 \mathrm{abc}$ & $3.64 \mathrm{a}$ \\
\hline SKN 39-10-19-29-12 & 11,12 & 2 & $11.12 \mathrm{ab}$ & 2.69 & $4.12 \mathrm{ab}$ & $8.28 \mathrm{a}$ & $2.19 \mathrm{ab}$ & $3.79 \mathrm{a}$ \\
\hline SKN 39-10-19-29-13 & 11,12 & 2 & $11.39 \mathrm{ab}$ & 2.66 & $4.28 \mathrm{ab}$ & $7.94 \mathrm{abc}$ & $2.11 \mathrm{c}$ & $3.78 \mathrm{a}$ \\
\hline SKN & - & 2 & $11.64 \mathrm{a}$ & 2.60 & $4.51 \mathrm{a}$ & $7.96 \mathrm{abc}$ & $2.14 b c$ & $3.73 \mathrm{a}$ \\
\hline RD6 NIL & $1,2,11,12$ & 2 & $9.91 \mathrm{c}$ & 2.81 & $3.53 c$ & $7.24 \mathrm{~d}$ & $2.22 \mathrm{a}$ & $3.26 \mathrm{~b}$ \\
\hline Mean & & & 11.1 & 2.65 & 4.2 & 7.89 & 2.16 & 3.66 \\
\hline F-test & & & ** & ns & $* *$ & $* *$ & * & $* *$ \\
\hline C.V. $(\%)$ & & & 3.8 & 3.95 & 5.74 & 2.87 & 1.92 & 3.46 \\
\hline
\end{tabular}

* Significant at $5 \%$ probability level; ${ }^{* *}$ Significant at $1 \%$ probability level; $\mathrm{ns}=$ non-significant differences; the letter after value were showed significant within the column. L/B ratio $=$ Length $/$ breadth ratio.

\section{Discussion}

Rice blast disease, caused by fungal pathogens, is a destructive disease, widely epidemic in Northeast Thailand. Blast disease also occurs in the more unfavorable upland conditions, where it also remains a serious problem. The major factor contributing to the incidence of blast disease is the bimodal distribution rainfall pattern within these areas [15], creating a humid climate, which occurs through all growth stages, particularly for leaf and neck blast.

The Rice Department of Thailand released Sakon Nakhon upland rice variety in 2000, and it has become the most popular rice variety grown in the upland areas of Northeast Thailand. However, this variety is highly susceptibility to blast disease. To date, an improved blast-resistant upland variety has not yet been released. In this study, success was achieved in improving blast resistance through MAS within the SKN variety, in which improved introgression lines demonstrated a high level of resistance compared with the original SKN.

Molecular markers have been wildly utilized as a tool for conventional breeding selection. The major objective of this study was to deliver blast resistant QTLs, while retaining the desirable aromatic traits of Sakon Nakhon rice. The presence of blast resistant QTLs of the SKN introgression lines and some the maintained agronomic attributes confirm the success of our marker-assisted backcross selection. As previously mentioned, the donor parent carries four resistant QTLs (two minor: $q B l 1, q B l 2$; and two major: $q B l 11, q B l 12)$. As the $\mathrm{BC}_{2} \mathrm{~F}_{1}$ population was small in size, selection for major QTLs was the first priority. This resulted in only two QTLs present in selected $\mathrm{BC}_{2} \mathrm{~F}_{2}$ lines, as smaller populations have been known to influence the number of QTLs produced when MAS is performed [38,39]. A larger population of perhaps 400 or more is therefore needed to more successfully backcross $F_{1}$ generations. In order to recruit all target QTLs, and retain a good genetic background of the recurrent parent; additional cycles of backcrossing must be performed [40].

Results from both greenhouse and field validations found that the selected lines of the QTL on chromosome 11 were greater in resistance than lines carrying the QTL on chromosome 12 (Tables 1 and 2). The region of blast resistance QTLs on chromosome 11 has been previously reported to possess numerous genes, including Pi-f, M-Pi-z, Pi-se-1,Pi-is-1, Pi-k, Pi-1(t),Pi-7(t) and Pi-a [27]. Within this study, the lines of the QTL chromosome 12 were susceptible. This was possibly caused by the QTL being nonspecific to the natural pathogen, and that the RM 27,933 used for selection was the only 
side marker within a distance of 8 centimorgan (cM), due to a low percentage of polymorphism. In such cases the phenotypic selection of resistant strains is better than genotype. A closer polymorphic marker is therefore needed for further study.

Jao Hom Nin, Azucena, and P0489 proved susceptible in the seedling stage, whereas IR 64 was resistant under greenhouse conditions (Table 3). In contrast, IR 64 was resistant to all isolates, due to its broad spectrum resistance of QTLs on chromosomes 2, 3, 8 and 12 [41]. The lack of resistance of the Jao Hom Nin, Azucena, and P0489 may be due to the over application of nitrogen in the seedling stage, which increases disease susceptibility and induces the susceptibility of rice resistant varieties [42,43].

Disease severity in the lowlands was greater than in the upland conditions (Figure 3), due to the high humidity present in the lowland paddy fields, allowing for favorable pathogen development and accumulation. Moreover, rice is grown year round in the lowlands as a monocrop culture. Also, upland rice is usually rotated with other field crops, such as sugarcane and cassava, thereby interrupting the pathogen life cycle [44]. However, the bimodal distribution of rainfall continues to foster disease outbreak.

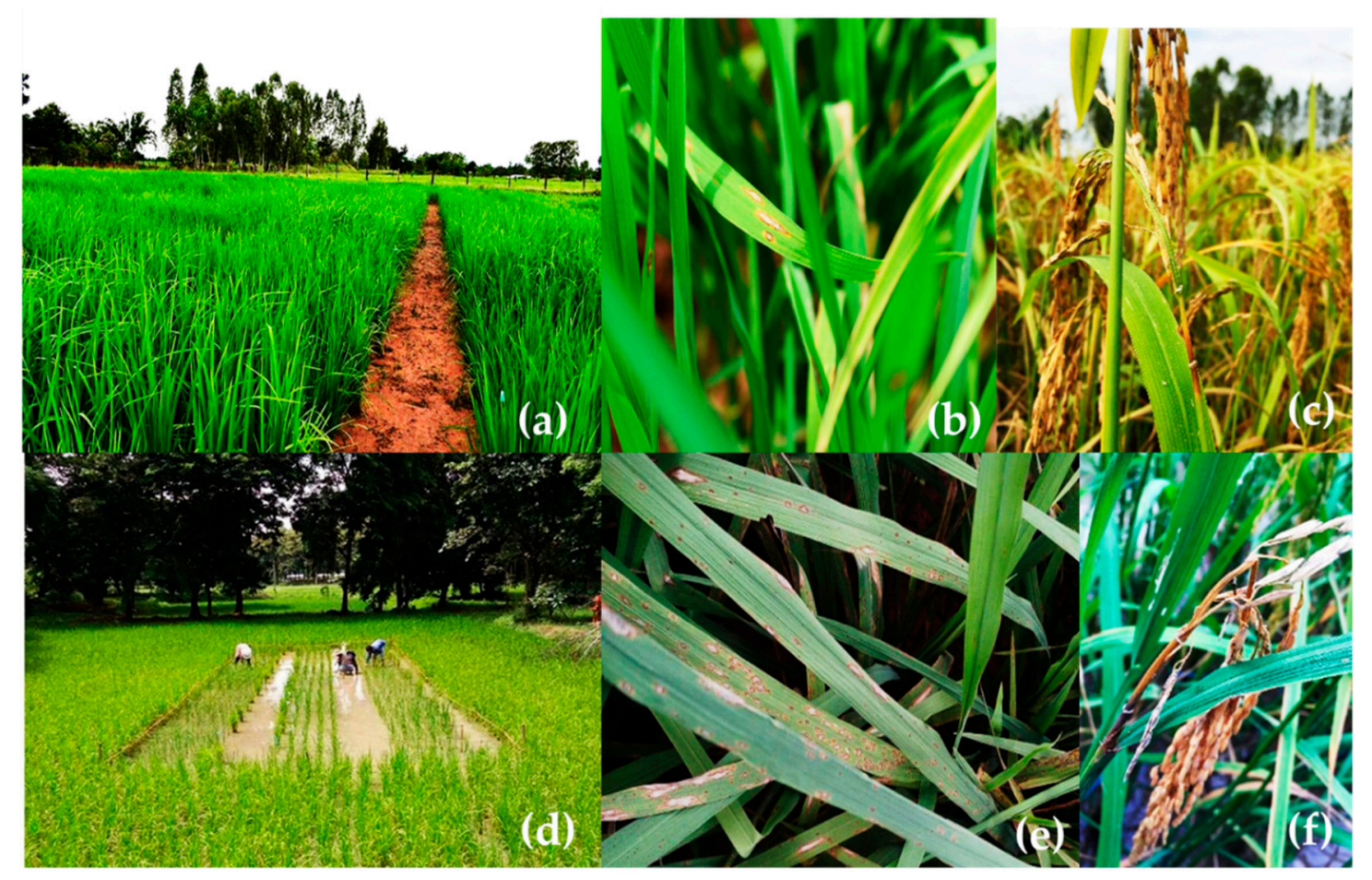

Figure 3. Field validation photographs of $\mathrm{BC}_{2} \mathrm{~F}_{4}$ progenies under upland condition at Ban Head; upland field (a), leaf blast (b), neck blast (c), and low land condition at KKU; low land field (d), leaf blast (e), and neck blast (f).

Although RD6 was susceptible to blast disease, neck blast was not present, as the flowering period did not match with the peak period of rainfall and high humidity (Figure $4 a-c)$. The results therefore prove that moisture on the panicle of rice has a direct effect upon the virulence of neck blast. On the other hand, SKN was susceptible to both leaf and neck blast (Table 2), confirming the necessary requirement for breeding resistance. The SKN introgression lines created exhibited resistance to leaf and neck blast on upland and lowland locations, especially in SKN 39-10-19-29-12, SKN 39-10-19-29-13, the lines with QTL on chromosomes 11 and 12, and the SKN 39-10-19-57-6 line with QTL in chromosome 11. All of which exhibited early flowering similar to that of the SKN recurrent parent; in contrast to the SKN, which flowered in the rainfall period, resulting in neck blast. Notably, the introgression lines were resistant, despite having the same flowering date as the SKN. We may therefore conclude that the SKN introgression lines are suitable to recommend in Thailand's bimodal rain pattern areas. 


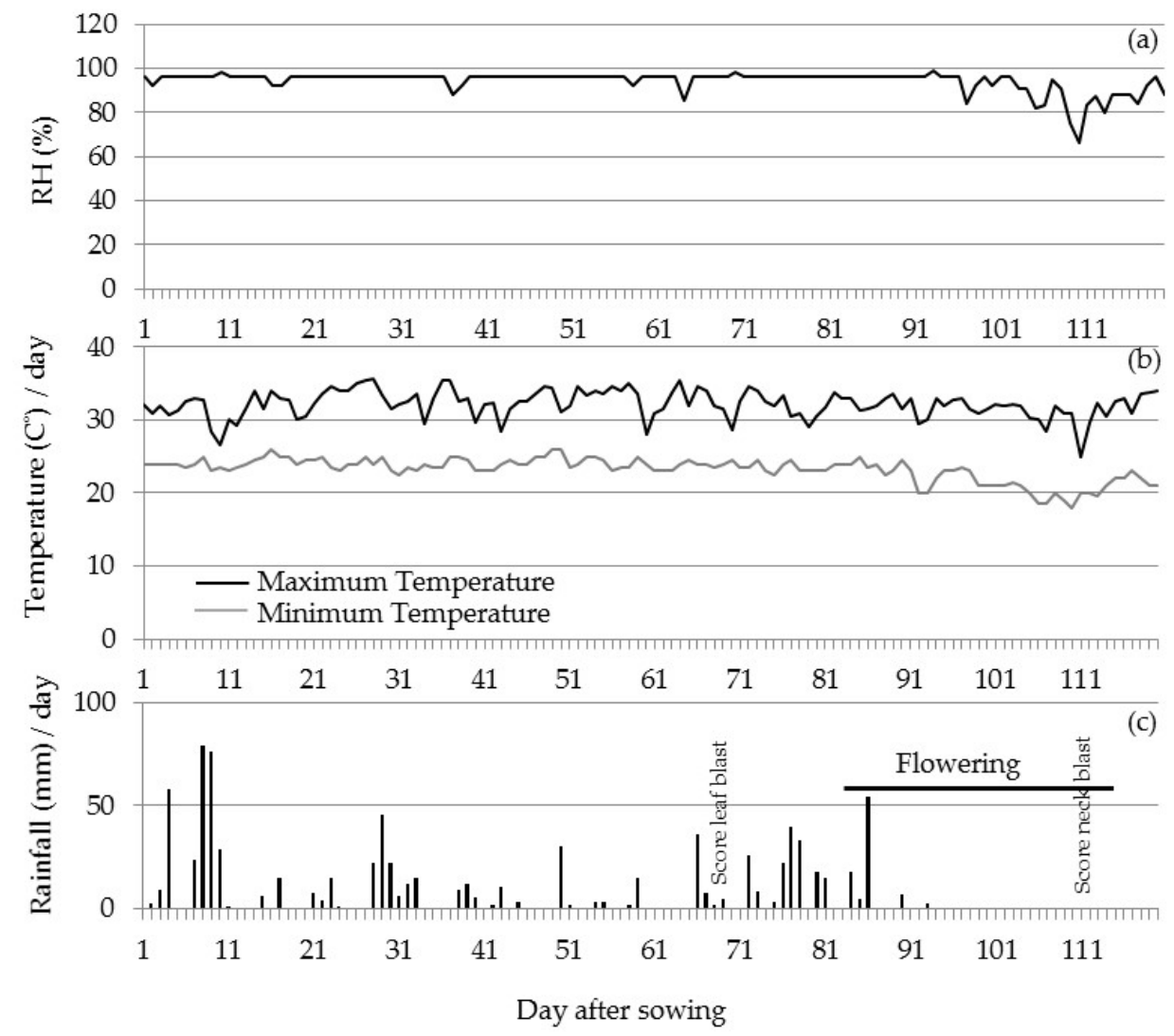

Figure 4. (a) Relative humidity ( $\mathrm{RH}, \%)$, (b) minimum and maximum temperature and (c) daily rainfall at the Khon Kaen field.

The blast-resistant $\mathrm{SKN}$ introgression line $\left(\mathrm{BC}_{2} \mathrm{~F}_{4}\right)$ maintained both the agronomic traits and yield performances (DF, PH, NEPT, PL, NGP, TGW, HI and GY) similar to the original SKN under both lowland and upland conditions of Northeast Thailand (Table 4). Generally, the introgression lines required five to six cycles in order to retain the recurrent parent's background [40]. Within our study, the donor parent (RD6 NIL) improved the agronomic traits and yields of the original SKN, indicating that a backcrossing cycle may not needed in order to retain the more recurrent parent background.

\section{Conclusions}

Improvement of the Sakon Nakhon upland rice cultivar for blast resistance was successfully achieved through marker-assisted backcrossing, together with phenotypic selection. The resulting introgression lines exhibited resistance to both leaf blast and neck blast in lowland and upland locations. Additionally, the agronomical traits and grain quality of the introgression lines were similar to those of the original Sakon Nakhon variety.

Supplementary Materials: The following are available online at http://www.mdpi.com/2073-4395/9/2/67/s1, Table S1: SSR Markers for blast resistance alleles detection, Table S2: Analysis of variance of $\mathrm{BC}_{2} \mathrm{~F}_{3: 2}$ selected line and check varieties against 4 isolates of Pyricularia oryza.

Author Contributions: Data curation: N.S., S.C. and T.M.; Formal analysis: N.S. and T.M.; Methodology: N.S., S.C., P.T. and J.S.; Resources: S.C., T.M., and J.S.; Software: T.M.; Supervision: S.C. and J.S.; Validation: N.S., S.C. and T.M.; Preparation of original draft: N.S. and S.C.; Writing, review, and editing: T.M., S.C. and J.S.

Funding: This research received no external funding.

Acknowledgments: This research was supported by The Plant Breeding Research Center for Sustainable Agriculture; The Research Center of Agricultural Biotechnology for Sustainable Economy, Khon Kaen University, Thailand; and The Ubon Ratchathani Rice Research Center (URRC).

Conflicts of Interest: The authors declare no conflict of interest. 


\section{References}

1. Office of Agriculture Economics. Agricultural Statistics of THAILAND 2015; Annual report of 2015; Ministry of Agriculture and Cooperatives: Bangkok, Thailand, 2015; p. 240.

2. Kharkwal, M.C.; Shu, Q.Y. The Role of Induced Mutations in World Food Security. In Induced Plant Mutations in the Genomics Era; Shu, G.Y., Ed.; Food and Agriculture Organization of the United Nations: Rome, Italy, 2009.

3. Lanceras, J.C.; Huang, Z.L.; Naivikul, O.; Vanavichit, A.; Ruanjaichon, V.; Tragoonrung, S. Mapping of genes for cooking and eating qualities in Thai Jasmine rice (KDML 105). DNA Res. 2000, 7, 93-101. [CrossRef] [PubMed]

4. Wani, S.P.; Pathak, P.; Sahrawat, K.L. Community Watershed Management for Sustainable Intensification in Northeast Thailand; International Crops Research Institute for the Semi-Arid Tropics: Andhra Pradesh, India, 2012; p. 152.

5. Jaruchai, W.; Monkham, T.; Chankaew, S.; Suriharn, B.; Sanitchon, J. Evaluation of stability and yield potential of upland rice genotypes in north and northeast Thailand. J. Integr. Agric. 2017, 16, 1-9. [CrossRef]

6. Prasunluk, N.; Athipanyakul, T. Production and marketing management of Sakon Nakhon rice and purple rice varieties in Khon Kaen province. KKU J. Health Sci. 2014, 2, 51-59.

7. Voraphab, I.; Hanboonsong, Y. The population of insect vector (Matsumuratettix hiroglyphicus (Matsumura)) and the incidence of sugarcane white leaf disease from upland rice rotation with sugarcane and sugarcane mono cropping system. Khon Kaen Agric. J. 2012, 3, 287-292.

8. Scardaci, S.C.; Webster, R.K.; Greer, C.A.; Hill, J.E.; William, J.F.; Mutters, R.G.; Brandon, D.M.; McKenzie, K.S.; Oster, J.J. Rice Blast: A New Disease in California; Agronomy Fact Sheet Series; Department of Agronomy and Range Science, University of California: Davis, CA, USA, 1997.

9. Kiyosawa, S. Genetics and epidemiological modeling of breakdown of plant disease resistance. Phytopathology 1982, 20, 93-117. [CrossRef]

10. Hu, H.-Y.; Zhuang, J.-Y.; Chai, R.-Y.; Wu, J.-L.; Fan, Y.-Y.; Zheng, K.-L. Isolation and characterization of defense response genes involved in neck blast resistance of rice. Acta Genet. Sin. 2006, 33, 251-261. [CrossRef]

11. Talbot, N.J. On the trail of a serial Killer: Exploring the biology of Magnaporthe grisea. Microbiology 2003, 57, 177-202. [CrossRef]

12. Katsube, T.; Koshimizu, Y. Influence of blast disease on harvest of rice plant. 1. Effect of panicle infection on yield components and quality. Bull. Tohoku Agric. Exp. Stn. 1970, 39, 55-96.

13. Skamnioti, P.; Gurr, S.J. Against the grain: Safeguarding rice from rice blast disease. Trends Biotechnol. 2009, 27, 141-150. [CrossRef]

14. Eamchit, S.; Mew, T.W. Comparison of virulence of Xanthomonas campestris pv. oryzae in Thailand and the Philippines. Plant Dis. 1982, 66, 556-559.

15. Jongdee, B.; Pantuwan, G.; Fukai, S.; Fischer, K. Improving drought tolerance in rainfed lowland rice: An example from Thailand. "New directions for a diverse planet". In Proceedings of the 4th International Crop Science Congress, Brisbane, Australia, 26 September-1 October 2004; pp. 1-14.

16. Michiaki, I. Probenazole-A plant defense activator. R. Soc. Chem. 2001, 12, 28-31.

17. Ashkani, S.; Rafii, M.; Shabanimofrad, M.; Miah, G.; Sahebi, M.; Azizi, P.; Tanweer, F.A.; Akhtar, M.S.; Nasehi, A. Molecular breeding strategy and challenges towards improvement of blast disease resistance in rice crop. Front. Plant Sci. 2015, 6, 886. [CrossRef] [PubMed]

18. Sharma, T.R.; Rai, A.K.; Gupta, S.K.; Vijayan, J.; Devenna, B.N.; Ray, S. Rice blast management through host-plant resistance: Retrospect and prospect. Agric. Res. 2012, 1, 37-52. [CrossRef]

19. Chen, J.; Shi, Y.; Liu, W.; Chai, R.; Fu, Y.; Zhuang, J.; Wu, J. A Pid3 allele from rice cultivar Gumei2 confers resistance to Magnaporthe oryzae. J. Genet. Genom. 2011, 38, 209-216. [CrossRef]

20. Ellur, R.K.; Khanna, A.; Yadav, A.; Pathaniaa, S.; Rajashekarab, H.; Singha, V.K.; Krishnana, S.G.; Bhowmicka, P.K.; Nagarajand, M.; Vinodd, K.K.; et al. Improvement of Basmati rice varieties for resistance to blast and bacterial blight diseases using marker assisted backcross breeding. Plant Sci. 2016, 242, 330-341. [CrossRef]

21. Sharma, B.; Pandey, M.P. Identification of rice germplasm with resistance to bacterial blight (Xanthomonas oryzae pv. oryzae). Bangladesh J. Agric. Res. 2012, 37, 349-353. [CrossRef] 
22. Basavaraj, S.H.; Singh, V.K.; Singh, A.; Singh, A.; Singh, A.; Yadav, S.; Ellur, R.K.; Singh, D.; Gopalakrishnan, S.; Nagarajan, M.; et al. Marker-assisted improve of bacterial blight resistance in parental lines of Pusa RH10, a superfine grain aromatic rice hybrid. Mol. Breed. 2010, 26, 293-305. [CrossRef]

23. Sivolap, Y.M. Molecular markers and plant breeding. Cytol. Genet. 2013, 47, 188-195. [CrossRef]

24. Koide, Y.; Kobayashi, N.; Xu, D.; Fukuta, Y. Resistance gene and selection DNA marker for blast disease in rice (Oryza sativa L.). Jpn. Agric. Res. Q. 2009, 43, 255-280. [CrossRef]

25. Fjellstrom, R.; Conaway-Bormans, C.A.; McClung, A.M.; Marchetti, M.A.; Shank, A.R.; Park, W.D. Development of DNA markers suitable for marker-assisted selection of three Pi genes conferring resistance to multiple Pyricularia grisea pathotypes. Crop Sci. 2004, 44, 1790-1798. [CrossRef]

26. Silprakhon, S. Identification and mapping genes controlling leaf blast resistance in double haploid lines IR64 $\times$ Azucena population. In Proceedings of the 1st International Conference on Rice for Future, Bangkok, Thailand, 31 August-3 September 2004.

27. Noenplab, A.; Vanavichit, A.; Toojinda, T.; Sirithunya, P.; Tragoonrung, S.; Sriprakhon, S.; Vongsaprom, C. QTL mapping for leaf and neck blast resistance in Khao Dawk Mali105 and Jao Hom Nin recombinant inbred lines. Sci. Asia 2006, 33, 133-142. [CrossRef]

28. Suwannual, T.; Chankaew, S.; Monkham, T.; Saksirirat, W.; Sanitchon, J. Pyramiding of four blast resistance QTLs into Thai rice cultivar RD6 through marker-assisted selection. Plant Breed. 2017, 53, 1-8. [CrossRef]

29. Manivong, P.; Korinsak, S.; Korinsak, S.; Siangliw, J.L.; Vanavichit, A.; Toojinda, T. Marker-assisted selection to improve submergence tolerance, blast resistance and strong fragrance in glutinous rice. Thai J. Genet. 2014, 7, 110-122.

30. Singh, A.K.; Gopalakrishnan, S.; Singh, V.P.; Prabhu, K.V.; Mohapatra, T.; Singh, N.K.; Sharma, T.; Nagarajan, M.; Vinod, K.K. Marker assisted selection: A paradigm shifts in Basmati breeding. Indian J. Genet. 2011, 71, 1-9.

31. Sreewongchai, T.; Toojinda, T.; Thanintorn, N.; Kosawang, C.; Vanavichit, A.; Tharreau, D.; Sirithunya, P. Development of elite indica rice lines with wild spectrum of resistance to Thai blast isolates by pyramiding multiple resistance QTLs. Plant Breed. 2010, 129, 176-180. [CrossRef]

32. Wongsaprom, C.; Sirithunya, P.; Vanavichit, A.; Pantuwan, G.; Jongdee, B.; Sidhiwong, N.; Siangliw, J.L.; Toojinda, T. Two introgressed quantitative trait loci confer a broad-spectrum resistance to blast disease in the genetic background of the cultivar RD6, a Thai glutinous jasmine rice. Field Crop Res. 2010, 199, $245-251$. [CrossRef]

33. Dellaporta, S.L.; Wood, J.; Hicks, J.B. A plant DNA minipreparation: Version II. Plant Mol. Biol. Rep. 1983, 1, 19-21. [CrossRef]

34. International Rice Research Institute. Standard Evaluation System for Rice (SES); International Rice Research Institute: Manila, Philippines, 2002.

35. Yi, M.; New, K.; Vanavichit, A.; Chai-arree, W.; Toojinda, T. Marker assisted backcross breeding to improve cooking quality traits in Myanmar rice cultivar Manawthukha. Field Crop Res. 2007, 113, 178-186. [CrossRef]

36. Sirithanya, P. Mapping Gene Controlling Blast Resistance in Rice (Oryza sativa L.). Ph.D. Thesis, Kasetsart University, Bangkok, Thailand, 1998.

37. Ahn, S.W. International collaboration on breeding for resistance to rice blast. In Rice Blast Disease; Zeigler, R.S., Leong, S.A., Teng, P.S., Eds.; Centre for Agriculture and Bioscience International (CABI): Wallingford, UK, 1994; pp. 137-153.

38. Witcombe, J.R.; Virk, D.S. Number of crosses and population size for participatory and classical plant breeding. Euphytica 2001, 122, 451-462. [CrossRef]

39. Hospital, F. Selection in backcross programmes. Philos. Trans. R. Soc. B 2005, 360, 1503-1511. [CrossRef]

40. Hasan, M.M.; Rafii, M.Y.; Ismail, M.R.; Mahmood, M.; Rahim, H.A.; Alam, M.A.; Ashkani, S.; Malek, M.A.; Latif, M.A. Marker-assisted backcrossing: A useful method for rice improvement. Taylor Francis J. 2015, 29, 237-254. [CrossRef] [PubMed]

41. Waiyalert, A.; Sreewongchai, T.; Chaisan, T.; Sripichit, P. Mapping of blast disease resistance genes in $\mathrm{BC}_{2} \mathrm{~F}_{6}$ population of the cross KDML105 $\times$ IR64. Kasetsart J. 2015, 49, 327-334.

42. Ballini, E.; Nguyen, T.T.T.; Morel, J.B. Diversity and genetics of nitrogen induced susceptibility to the blast fungus in rice and wheat. Rice 2013, 6, 1-13. [CrossRef] [PubMed]

43. Fageria, N.K. Nutrient management for improving upland rice productivity and sustainability. Commun. Soil Sci. Plant Anal. 2007, 32, 2603-2629. [CrossRef] 
44. Pooja, K.; Katoch, A. Past, present and future of rice blast management. Plant Sci. 2014, 3, 165-173. [CrossRef] (CC BY) license (http:/ / creativecommons.org/licenses/by/4.0/). 